\title{
ANALISIS DAMPAK PUTUSAN MAHKAMAH KONSTITUSI TERHADAP PENYELENGGARAAN PEMILIHAN GUBERNUR, BUPATI, DAN/ATAU WALIKOTA TAHUN 2020
}

\author{
Verlia Kristiani $^{1}$, Ahmad Redi ${ }^{2}$ \\ ${ }^{1}$ Program Studi Ilmu Hukum Universitas Tarumanagara \\ Email:verlia.205160122@stu.untar.ac.id \\ ${ }^{2}$ Fakultas Hukum, Universitas Tarumanagara \\ Email:ahmadr@fh.untar.ac.id
}

\begin{abstract}
Decision of the Constitutional Court brought steps to restore conditions of violation of constitutional rights. However, concrete procedures will result in the loss of the voting rights. Especially in vulnerable groups, such as indigenous peoples. The de jure dimension of suffrage and quality update are the embodiment of universal suffrage, the right to vote, the secret vote and the selection honestly. Then, the quality of the implementation of the election of regional heads is important, because the implementation of the elections can also have implications for the confidence of citizens or elections in democratic elections. Based on the explanation, the problem is how the effect of the Constitutional Court decision No. 20/PUU-XVII/2019 on the implementation of regional head election year 2020. This writing is normative legal research and is analytical descriptive. This writing analyzes the binding decision of the Constitutional Court, so that it impacts on various aspects. Therefore, description of the impact on social, political, legal aspects and so on is interrelated and part of the holding of the Regional Head Election. If the use of an electronic KTP or an electronic KTP recording certificate is applied to the Regional Head Election 2020, then it must be held in accordance with the election is carried out directly, publicly, freely, confidentially and fairly in the process of preparing for implementation and impacts on every aspect become the basis for the consideration of the holding of a Regional Head Election.
\end{abstract}

Keywords: decision of the Constitutional Court, voting rights, election of Regional Heads

\begin{abstract}
ABSTRAK
Putusan Mahkamah Konstitusi membawa langkah untuk berupaya memulihkan kondisi pelanggaran hak konstitusional. Namun, secara nyata prosedur tersebut akan menimbulkan kehilangan hak pilihnya. Terutama pada golongan rentan, seperti terjadi masyarakat adat. Secara de jure dimensi hak pilih dan pemutakhiran berkualitas adalah perwujudan terhadap hak pilih universal, hak untuk memilih, pemungutan suara yang rahasia dan pemilihan secara jujur. Kemudian, kualitas pelaksanaan pemilihan Gubernur, dan Bupati dan Walikota (selanjutnya disebut Pilkada) merupakan hal penting, karena pelaksanaan Pilkada dapat berimplikasi juga terhadap kepercayaan warga negara atau pemilih pada tahapan pemilu yang demokratis. Berdasarkan uraian tersebut, maka permasalahan yaitu bagaimana dampak putusan Mahkamah Konstitusi Nomor 20/PUU-XVII/2019 terhadap penyelenggaraan Pemilihan Kepala Daerah Tahun 2020? Penulisan ini merupakan pendekatan hukum normatif dengan cara melakukan penelaahan studi kepustakaan, jurnal-jurnal, atau berbagai materi dengan penulisan tersebut hukum normatif dan bersifat deskriptif analitis, sedangkan data sekunder dapat dari studi pustaka dan bahan tersier yaitu wawancara dan lain-lain. Penulisan ini menganalisis putusan Mahkamah Konstitusi yang mengikat, sehingga berdampak pada berbagai aspek. Dengan demikian, uraian-uraian dampak pada aspek sosial, politik, hukum dan sebagainya merupakan saling berkaitan dan bagian dari penyelenggaran Pilkada. Jika penggunaan KTP elektronik atau surat keterangan perekaman KTP elektronik diberlakukan pada Pilkada 2020, maka harus diselenggarakan sesuai pemilihan dilaksanakan secara langsung, umum, bebas, rahasia dan jujur adil dalam proses mempersiapkan penyelengaraan dan dampak-dampak pada setiap aspek menjadi dasar pertimbangan penyelenggaraan Pilkada nya.
\end{abstract}

Kata Kunci: putusan Mahkamah Konstitusi, hak pilih, pemilihan Kepala Daerah

\section{PENDAHULUAN}

\section{Latar Belakang}

Pemilihan umum (selanjutnya disebut Pemilu) merupakan alat terwujudnya oleh konstitusi dan hak untuk memilih Pejabat negara. Adanya pelaksanaan pemilihan umum di tingkat nasional 
atau daerah, dianggap sebagai alat pelaksanaan dari asas demokrasi serta karakter dan standar utama dari demokrasi. Pemilihan sebagai bentuk kekuasaan dan praktik pemerintah harus, didasarkan pada prinsip-prinsip hukum yang adil dan nilai-nilai yang berguna. Rancangan demokrasi harus dicapai melalui Pemilu yang demokratis yaitu good governance yang sejalan dan sesuai tuntutan rakyat (Tutik, 2006).

Dalam Penyelenggaraan Pemilu nasional diatur di pasal 22E Undang-Undang Dasar 1945, bertujuan untuk Pemilu calon presiden dan wakil presiden dan juga Pemilu calon legislatif. Sementara, di pasal 18 ayat 4 Undang-Undang Dasar 1945 dalam proses Pemilihan kepala daerah yaitu Gubernur, Bupati, dan Walikota (selanjutnya disebut Pilkada) yang dilaksanakan secara demokratis. Dalam regulasi secara lengkapnya mengenai pemilihan kepala daerah diatur dalam Undang-undang Nomor 10 tahun 2016 tentang pemilihan Gubernur, Walikota dan Bupati (selanjutnya disebut UU Pilkada). Namun, pada regulasi pemilihan calon Presiden dan Wakilnya, calon DPR atau DPRD dan/atau DPD yaitu telah digabung menjadi Undang-undang Nomor 7 Tahun 2017 tentang Pemilu (Abhan et.al, 2019). Dengan adanya ketentuan di pasal 348 ayat (9) Undang-undang Nomor 7 Tahun 2017 tentang pemilihan umum (selanjutnya disebut UU Pemilu), menimbulkan pengajuan judicial review ke Mahkamah Konstitusi. Pengujian dilakukan oleh pemohon yaitu yang diwakili oleh Titi Anggraini dari (Perludem) (selanjutnya disebut Pemohon I), Hadar Nafis (selanjutnya disebut Pemohon II) dan Feri Amsari Direktur Pusat Studi Konstitusi Fakultas Hukum Universitas Andalas (selanjutnya disebut Pemohon III), serta kemudian terdapat dua orang warga binaan di Lapas Tangerang, serta dua karyawan (Pengujian Undang-undang Nomor 7 Tahun 2017 Tentang Pemilu, 2019).

Selain itu, bahwa pemohon merasa dirugikan karena Pemilu dilaksanakan secara prosedur administratif, bisa menghambat dan mempersulit warga negara untuk menggunakan hak pilihnya. Pasal tersebut juga dapat berpotensi hilangnya hak konstitusional warga negara yakni hak memilih. Berdasarkan alasan-alasan di atas, maka para Pemohon memohon kepada MK memutus perkara secara bijak yaitu dalam pokok perkaranya yaitu: kesatu, memohon untuk menerima dan meluluskan permohonan seluruhnya. Kedua, menjadikan Pasal 348 ayat (9) Undang-undang Nomor 7 Tahun 2017 tentang Pemilu bertentangan dengan UUD 1945 dan inkonstitusional bersyarat sepanjang tanpa diartikan bahwa "hal tidak memiliki KTPelektronik dapat menggunakan kartu identitas lainnya, yaitu KTP non elektronik, surat keterangan, akta kelahiran, kartu keluarga, buku nikah, atau alat identitas lainnya yang bisa membuktikan yang bersangkutan mempunyai hak memilih, seperti Kartu Pemilih yang diterbitkan oleh Komisi Pemilihan Umum".

Dalam bentuk terpenuhinya syarat harus terdaftar sebagai pemilih kepada warga negara sebagaimana ditegaskan oleh UU Pemilu, KPU melakukan pendataan pemilih dan menyusun serta penetapan daftar pemilih. Proses pendataan dan penetapan daftar pemilih adalah suatu upaya penjaminan supaya setiap warga negara yang memiliki hak pilih terdaftar, sehingga dapat menggunakan hak pilihnya.

Berdasarkan alasan dari pemohon dan petitum, serta pertimbangan hukum dengan alasan yang kuat dan proporsional. Mahkamah Konstitusi memutus perkara pengujian Undang-undang Pemilu. Hakim mengabulkan sebagian di pasal 348 ayat 9 bahwa KTP elektronik dapat digantikan dengan Suket perekaman KTP agar bisa memilih. Dalam putusan MK perluasan frasa KTP elektronik yaitu menjadi termasuk pula surat keterangan perekaman KTP elektronik (selanjutnya disebut Suket KTP elektronik) itu membawa dampak positif yaitu terjadi peningkatan 81 persen partisipasi di Pemilu serentak tahun 2019 (Abhan et al, 2019). 
Pemilu serentak tahun 2019 telah selesai dilaksanakan, dan hal itu ada berbagai evaluasi secara keseluruhan dengan luas dan lengkap terhadap proses Pemilu. Hal tersebut itu menjadi bahan pertimbangan dalam pelaksanaan di Pemilu selanjutnya. ${ }^{1)}$ Pemilihan Umum selanjutnya yaitu Pemilihan Gubernur, dan Wakil, Bupati dan Wakil, serta Walikota Tahun 2020 (selanjutnya disebut Pilkada Tahun 2020). Mengingat ada 270 daerah yang akan mengikuti Pilkada serentak tahun 2020. (Anonim, 2019) Dalam pemilihan umum harus dilaksanakan dengan teliti dan cermat. Apabila tidak dilaksanakan secara teliti dan cermat, bisa meniadakan hak warga negara untuk memilih. Pada konkretnya adanya prosedur tersebut akan menimbulkan kehilangan hak pilihnya. Terutama pada golongan rentan, seperti terjadi masyarakat adat (Ramadhanil et. al, 2019).

Pada golongan masyarakat adat yaitu karena kondisi sosial budayanya, golongan tersebut tidak dapat melengkapi pada tahapan pendaftaran pemilih. Sehingga, namanya tidak tercantum dalam daftar pemilih dan biasanya masyarakat adat tersebut tidak memiliki KTP elektronik. Adapun karena masyarakat yang tinggal jauh di pedalaman hutan atau pegunungan, sehingga tidak bisa dijangkau oleh petugas pendaftaran pemilih.

Atas kejadian hilangnya hak pilih pada golongan rentan, menimbulkan prediksi persoalan tentang hak pilih di Pilkada 2020. Selain itu, dengan adanya alternatif Suket KTP elektronik dianggap masih tidaknya membatasi hak memilih. Selanjutnya, hak pilih adalah jaminan atas haknya harus dijaga dengan cermat. Oleh karena itu, ini menarik dikaji karena adanya perluasan frasa penggunaan KTP elektronik. Berdasarkan uraian di atas, akankah putusan tersebut berdampak pada berbagai aspek lainnya maupun pemenuhan konstitusional di Pilkada tahun 2020. Dengan demikian, maka penulis jabarkan dampak-dampaknya secara de jure maupun de facto.

Bagaimana dampak putusan Mahkamah Konstitusi Nomor 20/PUU-XVII/2019 terhadap penyelenggaraan Pemilihan Gubernur, Bupati, dan/atau Walikota Tahun 2020?

\section{METODE PENELITIAN}

Metode penulisan ini menggunakan pendekatan hukum normatif dengan cara melakukan penelaahan studi kepustakaan, jurnal-jurnal, atau berbagai materi dengan penulisan tersebut. Kemudian, spesifikasi penulisan yaitu penulisan dengan cara menggambarkan terhadap putusan atau kasus dan gejala yang terjadi pada masyarakat. Jenis dan sumber data penelitian ini adalah data sekunder dan melakukan wawancara dengan pihak Mahkamah Konstitusi, Perludem, dan anggota partai politik. Selain itu, data dikumpulkan informasi tersebut kemudian menganalisis data sekunder. Teknik yang digunakan dalam penelitian ini merupakan teknik kualitatif yang bersifat deskriptif analitis teknik analisa data yang digunakan untuk menganalisis dengan merumuskan data secara kalimat berdasarkan asas-asas hukum dan teori-teorinya. Sehingga dapat menarik kesimpulan dalam penulisan ini.

\section{HASIL DAN PEMBAHASAN}

Penyelenggaraan Pemilihan Gubernur, Bupati dan walikota 2020 yaitu ada 224 kabupaten, 37 Kota dan 9 Provinsi. Proses pelaksana Kepala Daerah dilakukan secara pemilihan umum, secara konstitusional diatur di pasal 18 ayat (4) UUD 1945 yaitu bahwa Gubernur, Bupati, dan Walikota (selanjutnya disebut Pilkada 2020) daerah provinsi kabupaten dan kota dipilih dengan 
demokratis. Dalam syarat dapat memilih yaitu selain masuk daftar pemilih tetapi juga memiliki KTP elektronik. Di Indonesia dalam pendaftaran pemilih masih bersifat kurang aktif. Maksudnya, bahwa pihak petugas lah yang mendata pemilih dengan mendatangi masyarakat dan pihak Rukun Warga maupun Rukun Tetangga untuk mendapatkan data penduduk yang telah terpenuhi syarat sebagai pemilih. Selain itu, apabila tidak masuk di daftar pemilih tetap, maka dapat menggunakan KTP elektronik agar bisa tetap memilih di pemungutan suara di Pemilu atau Pilkada. Berbeda kenyataan sebetulnya masih banyak yang masuk DPT tetapi tetap tidak dapat mengikuti pemilu dikarenakan belum semua pemilih melakukan perekaman KTP elektronik.

Berkaitan dengan frasa 348 ayat (9) tentang KTP elektronik sebagai syarat memilih dapat menimbulkan kerugian konstitusional terhadap warga. Sebab itu sebagaimana dinyatakan oleh alasan pihak pemohon MK Nomor 20/PUU-XVII/2019 bahwa, apabila seseorang yang tidak masuk di daftar pemilih tetap harus menggunakan KTP elektronik untuk bisa memiliki haknya. Selain itu, ketentuan tersebut menimbulkan menghambati, menghalangi dan mempersulit warga negara untuk memiliki hak untuk Pemilu, dengan demikian harus dibatalkan karena bertentangan dengan Undang-Undang Dasar 1945.

Berkenaan dengan KTP elektronik sebagai syarat sah memilih bagi warga negara, terjadi Perdebatan terhadap hilangnya hak pilih rakyat dalam Pilkada maupun Pemilu Presiden dan Legislatif dan semakin keras sejak diberlakukan pasal 57 ayat (2) UU Pilkada maupun Pasal 348 ayat (9) UU pemilu. Adanya penggunaan KTP elektronik, pemerintah sebagai pelaksana pencatatan sipil berkepentingan dapat menyerahkan data yang akurat di pemilu. Namun, di satu sisi pihak KPU mempunyai keperluan guna menjaga hak suara warga negara tidak satupun yang hilang.

Berangkat dari hal tersebut, maka aturan penggunaan KTP elektronik untuk memilih, seperti ada di pasal 348 ayat (9) UU Pemilu. Pasal tersebut menyatakan bahwa "Penduduk yang telah memiliki hak pilih sebagaimana dimaksud ayat (1) huruf d dapat memilih di TPS/TPSLN dengan menggunakan KTP elektronik". Akan tetapi KTP elektronik ini bisa digantikan menjadi Suket perekaman KTP elektronik. Suket perekaman KTP elektronik merupakan surat keterangan pengganti KTP elektronik, sesuai dengan kebijakan dari Kemendagri sebagai kepentingan untuk pemilihan calon Presiden dan calon Legislatif serta pemilihan Kepala Daerah maupun kepentingan lainnya. Faktor diperbolehkan suket KTP elektronik adanya amar putusan MK Nomor 20/PUU-XVII/2019 mengenai pasal 348 ayat (9) UU Pemilu. Di samping itu hubungan dari putusan ini, sesungguhnya pemilih yang menggunakan Suket perekaman KTP elektronik agar bisa memilih, hal itu mirip dengan pemilih yang mempunyai KTP elektronik dengan mana nantinya orang tersebut akan mempunyai KTP elektronik. Jadi putusan MK dalam hal suket perekaman hampir sama dengan KTP elektronik. Artinya hakim MK memberikan Suket perekaman hanya sebagai alternatif di mana seseorang belum memiliki wujud KTP elektroniknya.

Kemudian, terkait dengan putusan MK pasti tidak jauh dari adanya pengujian suatu undangundang terhadap UUD 1945. Putusan Mk memiliki sifat yang final dan mengikat. Adapun istilah kekuatan mengikat yaitu diartikan karena ada daya ikat. Menurut Mahmud Rasyid ada tiga aspek menjadi faktor daya ikat, yakni aspek hukum, aspek politik, dan moralnya. (Atmadja, 2015). Oleh karena sifatnya mengikat, maka akan menjadi norma yang harus dipatuhi kepada seluruh lapisan masyarakat maupun Negara. Di sisi lain, putusan Mk tersebut dianggap memberikan kemudahan dan dalam hal ini pemerintah dianggap lolos dari tudingan sebagai pihak yang paling 
bertanggung jawab atas nasib jutaan pemilih tidak dapat mengikuti pemilu karena belum memiliki KTP elektronik.

Berkaitan dengan hal tersebut, amar putusan MK Nomor 20/PUU-XVII-2019 tentang Pasal 348 ayat (9) UU Pemilu bisa diberlakukan juga di Pilkada 2020 perihal KTP elektronik. Putusan MK tersebut memuat sifatnya positif dan negatif terhadap penyelenggaraan Pilkada 2020. Sebelum menggambarkan dampak terhadap penyelenggaraan Pilkada 2020, di sini penulis mencoba melihat dari dampak yang lain setelah putusan Mk tersebut terkait penggunaan KTP elektronik atau Suket pada aspek-aspek lainnya. Berkenaan dengan hal tersebut, maka penulis menganalisis dampak putusan MK tentang Pasal 348 ayat (9) UU Pemilu dari berbagai aspek yang ada yaitu meliputi:

A. Aspek sosial dan budaya

Berkaca pada teori hak pilih sebagai HAM. Bahwa HAM yang diberikan masyarakat yaitu hak asasi yang menempel benar-benar pada diri manusia dan melaksanakan pun negara yang menjamin. Oleh karena sifatnya hampir sama dengan hak lainnya atau bersifat universal maka hak pilih pun meyakini sebagai hak dasar yang harus dipenuhi tidak melihat perbedaan atas bangsa, ras, ataupun jenis kelamin. (Rahmanto, 2019) Oleh karena itu, dampak putusan MK mengenai penggunaan KTP elektronik atau Suket perekaman terkait hak pemilihan berdampak pada aspek sosial dan budaya.

Berikut adalah beberapa dampak positif adanya putusan MK tentang Suket perekaman KTP elektronik dalam aspek sosial dan budaya yaitu:

1. Mempermudah bagi pemilih pemula yang baru berusia 17 tahun, dapat memilih dengan hanya menggunakan Suket perekamannya tersebut.

2. Ketika belum memiliki wujud KTP elektroniknya, masyarakat dapat menggunakan suket perekaman tersebut untuk mendaftar sebagai pemilih.

3. Mengakomodir masyarakat yang belum mempunyai KTP elektronik agar segera rekam data identitas resminya.

Selain dampak positif pasti ada dampak negatif yang terjadi. Berikut ini penulis menjabarkan data-data masyarakat yang belum memiliki KTP elektronik antara lain:

1. Masyarakat di Provinsi Jambi berjumlah 2\% yang belum memiliki KTP elektronik dikarenakan kondisi tempat tinggalnya yang jauh dari pusat pelayanan KTP elektronik. (Saragih, 2020) Adapun masyarakat di Halmahera Utara Maluku Utara belum memiliki KTP elektronik jumlah 7.557 orang warga dikarenakan masyarakat tidak mau mengurus KTP elektronik serta dalam proses perekaman KTP elektronik di kecamatan Loloda, Lolut, dan Kao Barat mendapatkan masalah jaringan internet yang sulit diakses. (Cermat, 2020)

2. Terdapat masyarakat adat yang tidak memiliki KTP elektronik. Masyarakat adat masuk sebagai warga hak pilih yang rentan memiliki KTP elektronik dikarenakan 3 (tiga) hal yaitu letak tempat tinggalnya yang jauh, terpencil dan sering berpindah akibatnya tidak mudah diakses. Kemudian, disebabkan Pemerintah yang tidak mengakui kepemilikan tanah ulayat (masyarakat adat) serta disebabkan masyarakat memiliki dasar kepercayaan adatnya. Seperti masyarakat Matoa berada di Kabupaten Bulukumba tidak memiliki KTP elektronik. Hal tersebut dikarenakan mereka mempunyai kepercayaan tidak boleh

difoto, mengingat bahwa setiap warga dalam proses perekaman KTP elektronik wajib difoto. (Salabi, 2019)

Berdasarkan data-data setiap warga yang belum merekam atau memiliki KTP elektronik, maka penggunaan KTP elektronik atau Suket perekaman KTP elektronik berdampak negatif pada aspek sosial dan budaya. Kemudian, dampak aspek sosialnya yaitu akibat penggunaan KTP 
elektronik maupun Suket perekaman sebagai syarat memilih yang berdampak dalam masyarakat daerah dan pedalaman atau masyarakat warga binaan di Lapas dan masyarakat lainnya. Hal tersebut dikarenakan beberapa faktor lainnya. Kemudian, hal tersebut berdampak juga pada budaya yaitu pada masyarakat adat karena ada beberapa faktor masyarakat adat tersebut tidak bisa memiliki KTP elektronik atau tidak bisa melakukan rekam KTP elektronik.

Berikut analisis dampak putusan MK tersebut pada aspek sosial dalam bentuk skema:

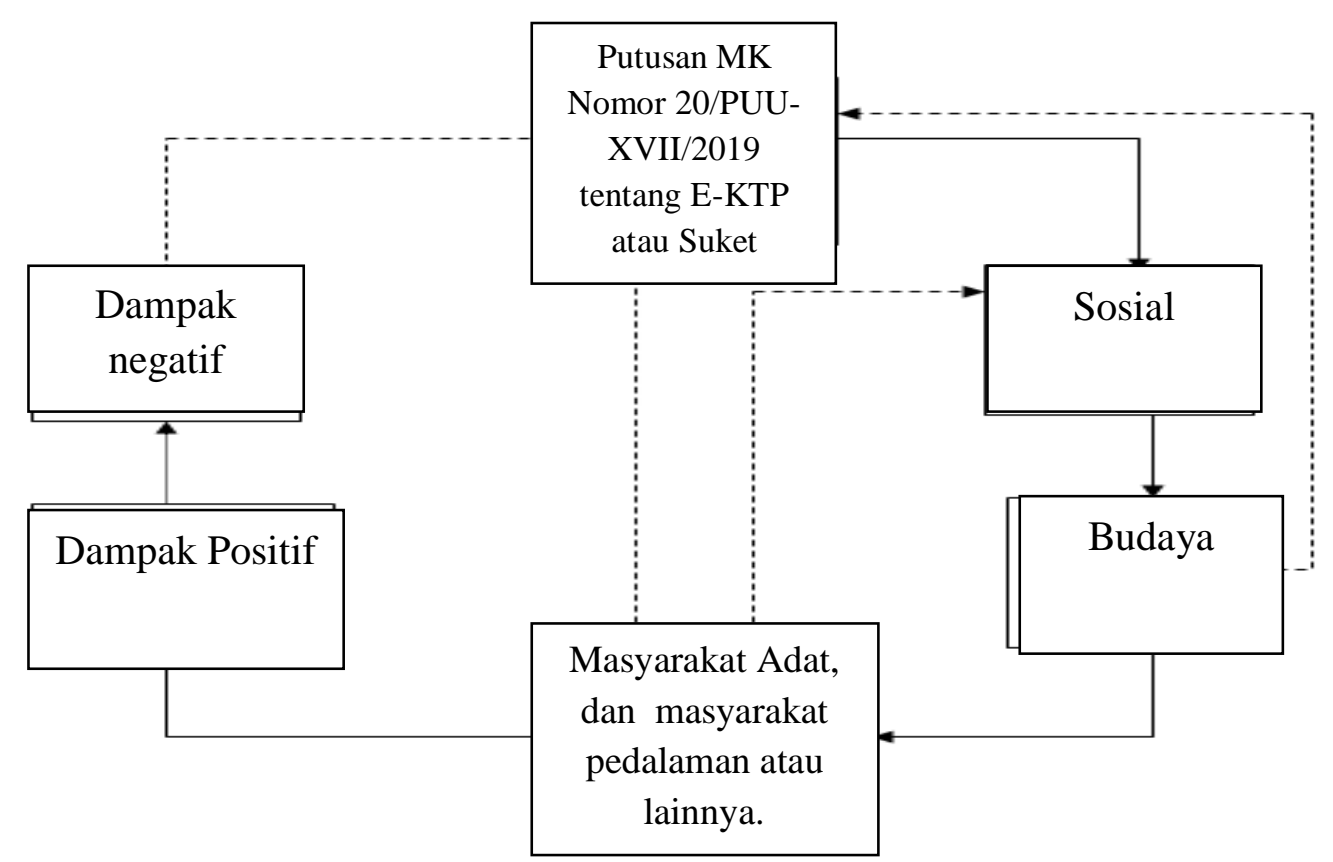

Gambar 1. Analisis Dampak Putusan MK Pada Aspek Sosial

B. Aspek hukum

Akibat putusan MK yang mengikat, maka pihak penyelanggara pemilu yaitu KPU RI mengeluarkan pasal 9 ayat (1) PKPU Nomor 9 Tahun 2019 tentang Perubahan Atas Peraturan KPU Nomor 3 Tahun 2019 Tentang Pemungutan dan Penghitungan Suara dalam pemilihan Umum. Selain itu, aturan dari Mendagri perihal Suket perekaman KTP elektronik yaitu surat edaran dari Dirjen Dukcapil Nomor 473.13/6153/Dukcapil tentang pelayanan rekam cetak KTP elektronik. (Disdukcapil, 2019).

Dengan demikian, uraian di atas merupakan contoh aspek hukum dikarenakan putusan MK berkarakter erga omnes. Hal tersebut membawa dampak bersifat positif pada kedudukan peraturan perundang-undangan atau perbuatan administrasi yang menyatakan sah. Dengan mana, diperbolehkan ketentuan suket perekaman KTP elektronik telah menjadi sah sebagai pemungutan suara. Di samping aspek hukum tersebut harus dimaknai dengan setiap sistem produk hukum perundangan yang berkaitan hak konstitusional kepada warga negara, seharusnya bisa memberikan kemudahan dan kelonggaran yang lebih untuk setiap warga negara dalam hak untuk memilih ataupun dipilih di Pemilu. Apabila ada pembatasan terhadap hak pilih warga negara yaitu sebuah pelanggaran konstitusional atau setiap warga negara dirugikan konstitusionalnya. Di sisi lain ketentuan Suket perekaman KTP elektronik sudah berlaku sah. Namun, hal tersebut menjadi dampak negatif yaitu banyaknya regulasi sebagai dasar hukum dan tidak sinkron dengan dasar penyelenggaraan Pilkada 2020 yaitu Undang-undang Nomor 10 Tahun 2016 tentang pemilihan Gubernur, Bupati, dan Walikota. Namun, apabila Pasal 348 ayat (9) UU pemilu 
tersebut dinyatakan inkonstitusional oleh $\mathrm{MK}$, maka UU tersebut dirancang kembali pada lembaga legislatif untuk diperbaiki. Di samping itu, hak pilih oleh HAM universal menyatakan negara wajib, "karena setiap negara diminta untuk mengeluarkan peraturan perundang-undangan dan usaha lain yang diperlukan untuk memastikan setiap warga negara tanpa diskriminasi berdasarkan apa pun memperoleh kesempatan yang efektif menikmati hak ini supaya tercapai lah kepastian hukum, keadilan dan kemanfaatan".

\section{Aspek politik}

Dampak politik disini berkaitan hak memilih masyarakat kepada calon wakil rakyatnya. Mengingat teori hak pilih dari Jimly Asshiddiqie yairtu ada pembagian beberapa kelompok tentang hak asasi manusia, yaitu dengan mana salah satu dari kelompok hak politik, ekonomi dan budaya. Dalam kelompok hak politik merupakan hak warga negara untuk memilih atau dipilih sebagai bentuk lembaga perwakilan rakyat.Kemudian, kehidupan politik yang demokratis akan membangun dengan bertahap berkelanjutan.

Berkenaan dengan hal tersebut, maka KTP elektronik merupakan produk politik. Selain itu aspek hukum terkait Peraturan KPU di mana mensyaratkan KTP elektronik atau Suket perekaman KTP elektronik sebagai syarat sah pemilih untuk menggunakan hak politik warga. Suket perekaman KTP tersebut diperbolehkan sebagai syarat memilih yang diharapkan membawa peningkatan partisipasi politik masyarakat terhadap Pilkada. Peningkatan partisipasi politik seperti meningkatnya partisipasi politik di pemilu 2019 yaitu terjadi peningkatan 81 persen. Namun, apakah Hakim MK atau Pemerintah perihal penggunaan KTP elektronik atau Suket tersebut sudah dipikirkan baik-baik tentang akan dampak pada hasil suara partai politiknya pada Pilkada 2020 nanti? Jika melihat dari data di beberapa daerah yang belum rekam KTP elektronik atau mempunyai KTP elektronik hal tersebut bisa berpotensi hak politik warga negara terhalangi karena persoalan administratif dengan mana akan berdampak pada kurangnya hasil suara partai politik.

Perihal dampak positifnya yaitu sebelum melakukan pencoblosan, bagi yang membawa suket perekaman KTP elektronik tetap pada syarat-syarat yang berlaku. Syaratnya yaitu agar bisa memilih bakal calon kepala daerah, maka alamat suket perekaman KTP elektronik harus sesuai dengan TPS/TPSLN. Artinya apabila alamat yang tercantum di Suket orang tersebut tidak sesuai dengan wilayah TPS maka tetap tidak bisa mencoblos. Bahwa ketentuan tersebut adanya hal menjamin ke akuratnya hasil suara untuk bakal calon Kepala Daerah.

D. Aspek ekonomi

Pada aspek ekonomi, berkaitan dengan akibat putusan MK tersebut menyatakan Suket perekaman bisa sebagai Pengganti KTP elektronik untuk pemungutan suara di pemilu akan berdampak pada keuangan negara. Hal tersebut menjadi dampak positif terhadap ekonomi di setiap Kabupaten/kota yaitu adanya suket perekaman KTP elektronik, Pemerintah atau Disdukcapil di Kabupaten atau Kota akan mendapatkan keuntungan ekonomi dikarenakan mendapatkan proyek mengadakan pemunculan Suket perekaman KTP elektronik. (Fachrudin, 2019) Kemudian, adapun berdampak pada penyelenggaraan yang bebas dan adil. Di mana penggunaan Suket perekaman KTP elektronik tidak memberikan kebebasan dan keadilan agar setiap masyarakat bisa ikut memilih. Secara konkritnya belum tentu semua diakomodir untuk melakukan pembuatan KTP elektronik. Seperti pada di suatu daerah alat perekamannya rusak, ataupun di daerah pedalaman susah diakses yaitu di wilayah papua. 
Terdapat dugaan-dugaan kerawanan yang akan terjadi pada di Pilkada serentak Tahun 2020, jika tidak diperhatikan dengan baik bisa mengakibatkan dampak negatif pada aspek penyelenggaraan bebas dan adil. Dengan demikian, uraian-uraian di atas terkait dampak pada aspek sosial, politik, hukum dan sebagainya merupakan saling berkaitan dan bagian dari penyelenggaran Pilkada 2020. Bagian penyelenggaaran Pilkada sesuai pasal 22E UUD 1945 yaitu pemilihan umum dilaksanakan secara Luber dan Jurdil yaitu dalam proses untuk mempersiapkan penyelengaraan dan dampak-dampak pada setiap aspek menjadi dasar pertimbangan penyelenggaraan Pilkadanya, apabila penggunaan KTP elektronik atau Suket perekaman KTP elektronik diberlakukan pada Pilkada 2020 nanti. Di sisi lain indikator KTP elektronik atau surat keterangan KTP elektronik, validasi mengukur seseorang itu benar bahwa itu pemilih yang dapat dipercaya.

Pemikiran Mahkamah Konstitusi tersebut bisa juga dipatahkan. Dipatahkan karena, seseorang memiliki KTP elektronik atau suket perekaman KTP elektronik belum tentu terjamin kebenaranya dan keasliannya. Bahwa dalam konkritnya secara teknis di TPS tidak ada alat validasi yang memastikan kebenaran, apakah KTP elektronik atau Suket perekaman KTP elektronik itu benar asli tidaknya. Jadi, salah satu peran penting validasi tidaknya itu, ada di petugas KPPS nya di TPS yang harus cermat dan teliti. Jika ditinjau lebih dalam, maka KTP elektronik atau Suket perekaman terhadap Pemilu yang jujur dan adil berhubungan erat dalam hal bertanggung jawab syarat administratif yang dipraktikan dalam penggunaan hak pilih maka KTP elektronik merupakan identitas resmi yang dapat dipertanggungjawabkan yaitu, KTP elektronik yang secara tegas menyatakan dalam UU Pemilu sebagai identitas resmi serta identitas lainnya tidak dapat ditempatkan setara dengan KTP elektronik sehingga keberadaannya juga tidak sama. Oleh sebab itu, menjadikan tepat KTP elektronik sebagai bukti identitas resmi dapat memilih dalam pemilu sudah tepat dan sesuai dengan proporsi.Jika ingin menghasilkan pemimpin pemerintahan negara yang berintegritas, maka butuh antisipasi terhadap kemungkinan terjadi kecurangan di penyelenggaraan Pilkada 2020. Hal tersebut dilakukan dengan cara yaitu, para pihak penyelenggara taat akan prosedur yang belaku dan memberikan pelayanan dalam melakukan coklit yaitu rumah ke rumah. (Anggraini, 2020) Selain itu, pihak KPPS atau PPS yang harus cermat dan teliti dalam memproses pemilihan yaitu di depan pintu masuk TPS nya.

\section{KESIMPULAN DAN SARAN}

Dampak KTP elektronik atau Suket KTP elektronik lebih membawa dampak negatif terhadap aspek sosial dan budaya. Kemudian, bahwa dampak putusan MK pada aspek hukum membawa dampak positif. Dikarenakan peraturan KPU tersebut mengikuti putusan MK dengan berubahnya ketentuan syarat memilih di peraturan KPU yang telah termuat pada PKPU tersebut. Selain itu, peraturan KPU tersebut dibentuk dalam rencana menentukan terwujudnya penyelenggaraan Pilkada yang sesuai dengan prinsip hukum yang nilai kemanfaatan dan ada berkeadilan.

Jika melihat dari data di beberapa daerah yang belum rekam KTP elektronik atau mempunyai KTP elektronik hal tersebut bisa berpotensi hak politik warga negara terhalangi karena persoalan administratif dengan mana akan berdampak pada kurangnya hasil suara partai politik. Oleh sebab itu, penulis memberikan kesimpulan bahwa dampak putusan MK tersebut memberikan dampak yang negatif pada aspek politik dan akan bermuara pada penyelenggaraan Pilkada yang Luber dan Jurdil. Penulis memberikan kesimpulan pada dampak positif pada aspek ekonomi yaitu Pemerintah atau Disdukcapil di Kabupaten atau Kota akan mendapatkan keuntungan ekonomi dikarenakan proyek mengadakan pemunculan Suket perekaman KTP elektronik. Selain itu, ada dampak negatif pada penyelenggaraan yang bebas dan adil yaitu Suket KTP elektronik tidak memberikan kebebasan dan keadilan kepada suatu daerah yang alat perekamannya rusak, ataupun di daerah pedalaman susah diakses. Berdasarkan hal tersebut, maka putusan MK belum 
memberikan kebebasan untuk setiap warga negara bisa mengikuti pemilu. Selain itu, terkait dampak pada aspek sosial, politik, hukum dan sebagainya merupakan saling berkaitan dan bagian dari penyelenggaraan Pilkada 2020 dan dampak-dampak tersebut menjadi dasar pertimbangan penyelenggaraan Pilkadanya, apabila penggunaan KTP elektronik atau Suket KTP elektronik diberlakukan Pilkada 2020 nanti.

Diharapkan Kementerian Dalam Negeri melakukan upaya pelayanan semaksimal mungkin untuk meningkatkan pencetakan KTP elektronik. Selanjutnya untuk pihak partai politik dan seluruh lapisan masyarakat bisa bekerjasama dalam penyelenggaraan Pilkada Tahun 2020

\section{Acknowledgement}

Penulis berterima kasih kepada berbagai pihak yang tidak dapat disebutkan satu persatu, atas kontribusinya dalam penelitian dan penulisan artikel ini.

\section{REFERENSI}

Abhan, Manik, Novida Ginting Evi., Fahriza, Telaumbanua, Berniawan Harlitus., Budhiati, Ida., Anggraini Erlya Nur., Sardini Hidayat Nur, Salam Roy, Ananingsih Wahyu Sri., Yulianto., Marzuki. (2019). Perihal Para Penyelenggara Pemilu Dalam Evaluasi Penyelenggaraan Pemilu 2019: Pengawasan dan Penegakan Keadilan Pemilu Serentak. Jakarta: Bawaslu.

Anonim. (2019, Juni). Ini 270 daerah yang gelar serentak Pilkada 2020. Retrieved maret 12 , 2020. Detik News: https://news.detik.com/berita/d-4596501/ini-270-daerah-yang-gelarpilkada-serentak-2020

Atmadja, D. G. (2015). Teori konstitusi dan konsep negara hukum. Malang: Setara Press.

Cermat, T. (2020, Maret). Warga di Halmahera Utara Malut, belum miliki E-KTP. Dipetik Mei 25, 2020. Kumparan: https://kumparan.com/ceritamalukuutara/7-557-warga-dihalmahera-utara-malut-belum-miliki-e-ktp-1t3UkpDW5JG/full

Disdukcapil. (2019, September). Surat edaran Mendagri. Retrieved Mei 29, 2020. Disdukcapil Kota https://disdukcapil.pontianakkota.go.id/public/uploads/files/Disdukcapil_Kota_Pontianak _2946367585_SE_47113_6153_DUKCAPIL_tentang_pelayanan_rekam_cetak_KTP.el.p df

Fachrudin, A. (2019). Dampak putusan MK nomor 20 tahun 2019. Dipetik Mei 26, 2020. DetikNews: https://news.detik.com/kolom/d-4501189/dampak-putusan-mk-nomor-20tahun-2019

Pengujian Undang-undang Nomor 7 Tahun 2017 Tentang Pemilu, 20/PUU-XVII/2019 (Mahkamah Konstitusi Maret 2019). https://mkri.id/public/content/persidangan/putusan/putusan_mkri_5355.pdf

Rahmanto, T. Y. (2019). Hak Pilih Bagi Penyandang Disabilitas Mental Ditinjau Dari Perspektif Hak Asasi Manusia. Jurnal HAM . 10 (1) 8. Diakses dari doi: http://dx.doi.org/10.30641/ham.2019.10.19-37

Ramadhanil. (2019). Perlindungan hak memilih warga negara di Pemilu 2019 dan keterwakilan perempuan di Lembaga Penyelenggara Pemilu. In Perludem, Buku Pemilu. Jakarta: Perludem.

Salabi, A. (2019, September 27). Evaluasi hak memilih di Pemilu 2019 kondisi khusus perlu tindakan khusus. Retrieved Mei 2020. Rumah pemilu: https://rumahpemilu.org/evaluasihak-memilih-di-pemilu-2019-kondisi-khusus-perlu-tindakan-khusus/ 
Saragih, R. (2020, Februari 23). Jelang Pilkada serentak 40.000 penduduk Jambi belum miliki EKTP. Retrieved mei 2020. Berita Satu: https://www.beritasatu.com/nasional/602153jelang-pilkada-serentak-40000-penduduk-jambi-belum-miliki-ektp

Tutik, T. T. (2006). Pokok-pokok hukum tata negara Indonesia. Jakarta: Prestasi Pustaka. 